\title{
Christ also ours in Africa: A consideration of Torrance's incarnational, Christological model as nexus for Christ's identification with African Christians
}

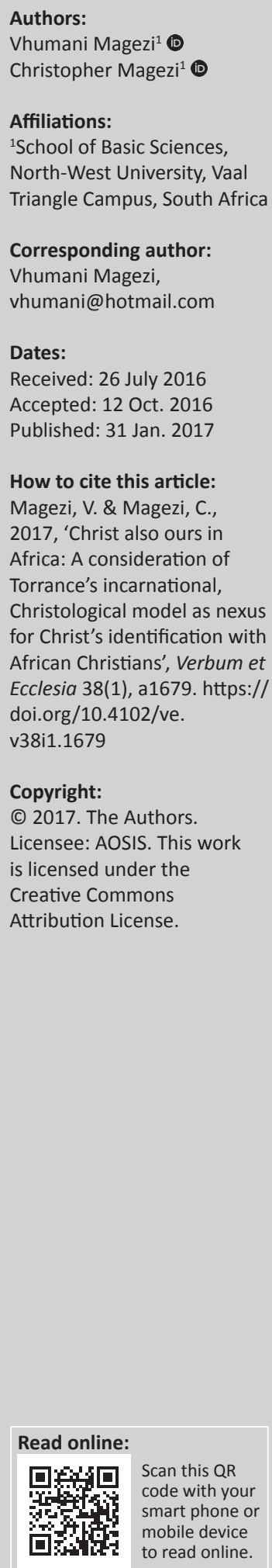

\begin{abstract}
The perceived foreignness of Christ in African Christianity is an ongoing challenge that is captured in various pieces of African theological literature. This problem partly arises from some early Western missionaries' presentation of the gospel to Africans from a predominantly Western perspective, which caused many Africans to perceive Christ as a Western Saviour with a Western identity. The problem of the foreignness of Christ in African Christianity is further intensified by the traditional African ancestral world view that requires a blood-related ancestor to address the African contextual needs. Therefore, many African Christians do not like to view Christ as identifying with them. This has resulted in the unchanging ethical lives of some African Christians as Christ and the consequent Christian ethics have not taken deep roots. To inform the identity and ethical lives of African Christians as true followers of Christ, many African theologians have responded to the foreignness of Christ in African Christianity by proposing various African Christological approaches that identify Christ with African Christians. However, these Christological approaches are limited in various ways. Thus, in the quest for an alternative Christological model that identifies Christ with African Christians, this article critically analyses and evaluates Torrance's incarnational Christological model in order to determine how his (Torrance's) incarnational Christological conceptualisation can open up aspects of Christ's incarnation that fully identify Christ with African Christians. The article highlights that Torrance's incarnational Christological concepts, namely, anypostasis and enhypostasis, the close association between the doctrine of creation and redemption, and the interpretation of the redemptive history of Israel from an incarnational perspective configures that in the incarnation, God in Christ completely identifies with all humankind and saves them from the ontological depth of their existence. Hence, Torrance's incarnational Christological model has the significant implication that the gospel is for all humanity in its dealing with sin and spiritual forces. African Christians may claim complete solidarity with Christ everywhere without the stumbling block of a claimed foreignness of Jesus Christ. This article contributes to African Christian identity discussion by identifying a constructive way of understanding Christ's salvation in a manner that effectively communicates Christ's relevancy to African Christians. As such, it contributes to systematic theological discussion on Christ in Africa from a Christian identity perspective and its soteriological implications.

Intradisciplinary and/or interdisciplinary implications: The article focuses on interdisciplinary, that is, systematic theology and missiology (African Christian identity). The article contributes to identifying a constructive way of understanding Christ's salvation in a manner that effectively communicates Christ's relevancy to African Christians. As such, it contributes to a systematic theological discussion on Christ in Africa from a Christian identity perspective and its soteriological implications.
\end{abstract}

\section{Introduction}

Within the ongoing debate of Christ's foreignness in Africa and the available Christological models, it is important to develop an alternative Christological model that identifies Christ with African Christians. In this regard, Torrance's incarnational Christological model provides an incarnational Christological conceptualisation that can open up aspects of Christ's incarnation that fully identifies Christ with African Christians. This article advances this argument.

\section{Study background: A terrain sketch and problem identification}

It is maintained by various Scholars that Christ and consequently Christianity in Africa is viewed as a Western project (Banda 2005:5; Bosch 1993:264-267; Chitando 2005:184; Magezi 2016:27-33; 
Taylor 1963:16). This is because some early Western missionaries' 'cultural superiority informed their approach, with a conflation between Christianity and European culture shaping their vision' (Banda 2005:2-6; Chitando 2005:184; Magezi 2016:29-33). In doing this, these missionaries have painted Christ as a Westerner and the saviour with a Western world view, that is, making Christ irrelevant and foreign in addressing the African contextual needs (Banda 2005:5). In other words, the early Western missionaries' presentation of Christ in Africa as a Western saviour with a Western identity has resulted in the failure of many Africans' perception of Christ identification and solidarity with them (Banda 2005:26; Chitando 2005:184; Magezi 2016:29-33; Taylor 1963:16). This is why Taylor (1963) argued that:

Christ has been presented as the answer to the questions a white man would ask, the solution to the needs that western man would feel, the Saviour of the world of the European world-view, the object of the adoration and prayer of historic Christendom. But if Christ were to appear as the answer to the questions that Africans are asking, what would he look like? (p. 16)

The perceived foreignness of Christ in African Christianity has caused many African Christians' continual use of traditional African powers (i.e. ancestors and traditional African medical practitioners) to address their religious spiritual threats such as witchcraft and angry ancestral spirits $^{1}$ (Banda 2005:2-6; Magezi 2016:1-34, 29-33). That is, because of the unrelatedness of Christ with Africans, many African Christians are uncertain about 'how the Jesus of the Church's preaching saves them [African believers] from the terrors and fears that they experience in their traditional world-view' (Bediako 2004:23). Efforts to respond to the proposed challenge of the foreignness of Christ in African Christianity have resulted in proposals of various Christological models. Many African theologians have attempted to translate the gospel into various traditional African categories and concepts which are familiar to African Christians (Igba 2013:3; Oborji 2008:15-17). This method 'reflects on the gospel, the Christian tradition, and the total Christian reality in an African manner and from the perspectives of the African world-view' (Oborji 2008:15) (also see Magezi \& Magezi 2016a). Oborji identifies many Christological models that have been employed by African theologians in enhancing Christ's complete identification with Africans. In making Jesus Christ familiar and relevant to Africans, many African theologians have designated 'Jesus as the liberator, the ancestor, the healer, the African king and the African chief' (Oborji 2008:16). The treatment of Christ

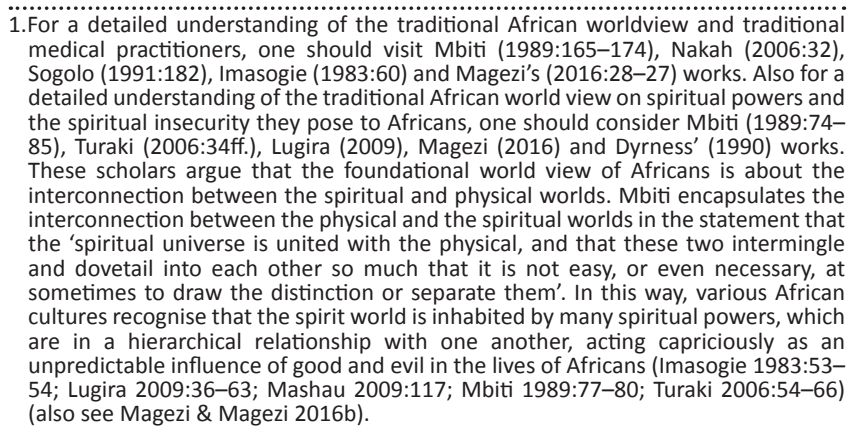
medical practitioners, one should visit Mbiti (1989:165-174), Nakah (2006:32), Sogolo (1991:182), Imasogie (1983:60) and Magezi's (2016:28-27) works. Also for detailed understanding of the traditional African world view on spiritual powers and the spiritual insecurity they pose to Africans, one should consider Mbiti (1989:7485), Turaki (2006:34ff.), Lugira (2009), Magezi (2016) and Dyrness' (1990) works. These scholars argue that the foundational world view of Africans is about the interconnection between the spiritual and physical worlds. Mbiti encapsulates the interconnection between the physical and the spiritual worlds in the statement that interconnection between the physical and the spiritual worlds in the statement that the 'spiritual universe is united with the physical, and that these two intermingle and dovetail into each other so much that it is not easy, or even necessary, at sometimes to draw the distinction or separate them'. In this way, various African cultures recognise that the spirit world is inhabited by many spiritual powers, which are in a hierarchical relationship with one another, acting capriciously as an unpredictable influence of good and evil in the lives of Africans (Imasogie 1983:5354; Lugira 2009:36-63; Mashau 2009:117; Mbiti 1989:77-80; Turaki 2006:54-66)
(also see Magezi \& Magezi 2016b).

under the category of ancestor is viewed by Wacheche (2012:27) and Oborji (2008:16) as the leading African Christological approach that many African theologians tend to follow. For example, Bediako (1994:93-121), Bujo (1992:79), Nyamiti (2006:24), Pobee (1979:94), Milingo (1984:85), Kwesi (1984:197-198), Kabasele (1991:123-124) and many others are approaching the subject of Christology from an ancestral perspective (also see Magezi \& Magezi 2016a).

Perhaps, the treatment of Christ under the category of ancestor has gained popularity in the academic literature because inherent within the African traditional world view is ancestral veneration, which occupies a central place in traditional African religion (Dyrness 1990:48; Reed \& Mtukwa 2010:148; Triebel 2002:193). The ancestors are those bloodrelated members of the family, clan or tribe who have lived an outstanding life and who have supposedly thereby acquired supernatural powers after death, which enable them to function as both guardians and protectors of their living descendants (Bediako 2004:23; Lugira 2009:48-50; Nyamiti 2006:3, 9; Oladosu 2012:160-161) (also see Magezi \& Magezi 2016b). Hence, for Christ to be accepted by Africans and fulfil the expected responsibilities in addressing the African contextual needs (which is believed by Africans to be the role of ancestors and other African traditional practitioners), the overarching concern however is about the familial relationship between Jesus Christ of Nazareth and African people because the two do not belong to the same 'clan, family, tribe and nation' (Bediako 2004:23; cf. Pobee 1979:81; Reed \& Mtukwa 2010:158-161, see also Magezi \& Magezi 2016a, 2016c).

Nonetheless, the African Ancestral Christological approach poses a challenge to an ordinary Christian in the sense that they struggle to identify with this category. Palmer (2008:65) affirms that many Protestant and Catholic theologians 'have referred to Jesus as an ancestor. Yet at the grass-roots there is still significant resistance to such a concept'. The fact that the application of the ancestral category to Christ is being resisted at grassroots level is of serious concern. Tienou (1990:76) advised that African Christian theologies should not be produced in theological institutions and universities alone but through the communal efforts of the entire church. Bowers (2002), concurring with Tineou, added that the nature of the African theological enterprise requires that the 'defining matrix be the present Christian community of Africa with the full range of its needs and expectations, its requirements and preoccupations' (Bowers 2002:122). Thus the defining matrix in African Christianity should be the way and the manner it is understood by popular Christians. Maybe the ancestral category is resisted because although it takes the traditional African ancestral world view seriously, it is also true that it reveals a tendency of diminishing the actuality of Christ as God incarnate and encouraging syncretism in African Christianity (Magezi 2016:63-66; Mkole 2000:1138; Palmer 2008:65-76; Reed \& Mtukwa 2010:144-163). Reed and Mtukwa (2010:144-163) and Magezi (2016:64-66) 
contend that Christ, because he is God incarnate, transcends the African ancestral category which makes the concept unsuitable for a biblically based Christology. This quest was the cry of Biang Kato (1975) before his sudden death, as highlighted by Bowers (2009:91-94). Kato advised against the dangers of Christological models that seem to be strongly leaning towards African traditional ancestral worship to the extent of diminishing the biblical distinctiveness of Christ (Bowers 2009:91-94). Reed and Mtukwa (2010:144-163) and Magezi (2016:65-66) further argue that it is unhelpful to force the preconceived African ancestral category on Christ because it encourages African Christians to continue to think of Christ in the categories of their natural ancestors, which is an element that African Christians desire to clearly view as having cut off.

Generally, the regrettable consequences of the Christological African approaches are their conflation with African nationalism which has resulted in only focusing on African cultural assertion in a manner that is uncritical to African life patterns and contemporary African challenges (Bowers 2009:91-114; Gifford 2008:1834). At stake therefore in Africa is the following issue: how could Christ and consequently Christianity be truly identified with African Christians? This poses the challenge of identifying or developing a legitimately biblical and sound Christological model that truly identifies Christ with African Christians. Among the various systematic theologians who have written on Christology particularly from the perspective of a complete solidarity and identification of Christ with all humanity, Thomas F. Torrance stands out (hereafter called Torrance).

Torrance was a Scottish Protestant theologian, who was born to missionary parents in China in August 1913 (Cassidy 2008:165). Many of Torrance's contemporary theologians regarded him as one of the most significant theologians in Europe and beyond (McGrath 1999:xi). McGrath (1999:xi) argues that the significance of Torrance is apparent in the numerous 'doctoral theses devoted to an analysis of aspects' of his thought. This suggests that Torrance was 'a man of ideas who ha[d] a passion for the life of the mind as it is encountered by the reality of God' (McGrath 1999:xiii).

In view of Torrance's incarnational Christology, Kettler (1991) sharply argued that Torrance stands out as:

$[O]$ ne contemporary theologian who has repeatedly in his writings brought up the significance of the vicarious humanity of Christ for salvation. This is a humanity which becomes the basis for a renewed and restored humanity. Certainly such an approach holds promise to help us in our search for the reality of salvation. (p. 121)

This reality maintained by Torrance has significant implications for African Christians in terms of their identification with Christ and their consequent identify as Christians. Given this, this article critically analyses and evaluate Torrance's incarnational Christological model. This is done in order to determine how Torrance's incarnational Christological conceptualisation can open up aspects of
Christ's incarnation which fully identifies Christ with African Christians. This will be done by engaging directly with Torrance's own work, as well as complementary sources to his work.

In order to achieve this article's objective stated above, the first section establishes Torrance's ontological inclusivity of all humankind in the vicarious humanity of Jesus Christ. This will be done by bringing to the fore Torrance's incarnational Christological concepts, such as the vicarious humanity of Christ, determined by the two concepts from Greek patristic theology, namely, the anhypostasis and ehypostasis union. Anhypostasis affirms the negative that the human nature of Christ is without an independent personal centre, whilst enhypostasis affirms the positive that the human nature finds its centre and expression in the person of the eternal Son of God. This section will proceed to discuss Torrance's delineation of the connection between the doctrines of creation and redemption, and the interpretation of Israel's redemptive history from an incarnational perspective. The second section identifies the significance of the foregoing Torrance's incarnational Christological concepts in enhancing Christ's identification with African Christians. Once this is done, the article concludes by arguing that Torrance's incarnational Christological model has the implication that God in Christ identifies with all humankind and saves them from the ontological depth of their existence. This section includes an engagement with African ancestral category in the light of Torrance's Christology. This will demonstrate that the gospel is for all humanity in its dealing with $\sin$ and spiritual forces. Therefore, African Christians may claim complete solidarity with Christ everywhere without the stumbling block of a claimed foreignness of Jesus Christ.

\section{The ontological inclusivity of all humankind in the vicarious humanity of Jesus Christ}

\section{The vicarious humanity of Christ: Anhypostasis and enhypostasis in Torrance's incarnational Christological mode}

In upholding the evangelical doctrines of the Trinity and Christology, Torrance (1996:18) asserts that Jesus Christ was both fully God and fully man in nature. That is, in Torrance's (1996) view, the incarnation:

constitutes the one actual source and the one controlling center of the Christian doctrine of God, for he who became man in Jesus Christ in order to be our Savior is identical in Being and Act with God the Father. (p. 18)

In underscoring this, Torrance (2008:231) proceeds by delineating the nature of the vicarious humanity of Christ (as the representative of all humanity) in relation to our salvation. Torrance (2008:84, 230-232, 2009:1xxii) understands that in the incarnation, there is a once and for all solidarity between 'Christ and all mankind'; therefore, the incarnational human nature of the divine Logos identifies with all people. 
Torrance (2008:84) arrived at his conclusion about the ontological inclusivity of all humankind in the vicarious humanity of Jesus Christ by his utilisation of the two inseparable Greek patristic theological concepts (which are the two qualifications that need to be made about the relation of the humanity of Christ to his divine person), namely, anhypostatic and enhypostatic union (Torrance 2008:230, 2009:Ixxii-lxxiii). These Greek theological concepts determine Torrance's (2008:233) doctrine of the vicarious humanity of Christ, hence his soteriological Christology. Concerning the anhypostatic union, Torrance (2008:84, 229, 2009:1xxiii) agrees with Barth (1958:49) and Moltmann (1974:231) that this concept asserts the negative, i.e. that the general or common human nature of Jesus Christ has no independent grounding. The concept of enhypostatic union affirms the positive that in the incarnation, the human nature of Christ is grounded in the eternal person of the divine Logos, which implies that the human nature of Christ acquires real existence and stability in the existence of God (Barth 1958:49; Torrance 2008:84, 230) (also see Magezi \& Magezi 2016a). Thus, Bavinck (2006) is right in concurring with Torrance that the human nature of Jesus Christ:

$[H]$ ad no personal existence in him alongside the Logos but was from the very beginning so prepared by the Holy Spirit for union with the Logos and for his work that in that Logos it could represent the entire human race and be the mediator of God for all humans of all the races and classes and age groups of all times and places. (p. 306)

Torrance's promoter, Barth (1958:49), conceives the potential objection which is associated with the enhypostatic concept, especially in its relationship to the doctrine of the vicarious humanity of Christ (hence, Christology). He stated that the concept of enhypostastic union seems to deny the actual humanity of Christ (docetism), if not understood properly (Barth 1958:49) (also see Magezi \& Magezi 2016a). Nevertheless, Torrance's explanation of the concept of enhypostatic union is cognisant of the aforesaid challenge because Torrance qualified what he means and does not mean by his use of the enhpostastic concept. That is, by employing the concept of enhypostatic union to the vicarious humanity of Christ, Torrance (2008:230) does not mean that 'in the incarnation there was no particular individual called Jesus existing as a particular human being, with a rational human mind and will and soul'. Instead, Torrance (2008:230) believes that Jesus was a true human being, who possessed a full 'human mind and human soul and human will' in his 'hypostatic union with divine life' (also see Magezi \& Magezi 2016a).

Given the aforementioned challenge, Torrance (2008) further encapsulates the couplet significance of the anhypostastic and enypostastic concepts in relation to the doctrine of the vicarious humanity of Christ, as he argues that:

the anhypostasia stresses the general humanity of Jesus, the human nature assumed by the Son with its hypostasis in the Son, but enhypostasia stresses the particular humanity of the one man Jesus, whose person is no other than the person of the divine Son. (p. 230)
Importantly, the concepts of 'anhypostasis and enhypostasis' are:

a very careful way of stating that we cannot think of the hypostatic union statically, but must think of it on the one hand, in terms of the great divine act of grace in the incarnation and on the other hand, in terms of the dynamic personal union carried through the whole life of Jesus Christ. (Torrance 2008:84)

To put it differently, in Torrance's (2008) view, the anhypostatic and enhypostatic concepts can be summarised in the following way:

The anhypostatic assumption speaks of God's unconditional and amazingly humble act of grace in assuming our humanity in the concrete likeness of the flesh of sin. But within that, enhypostasia speaks of the fact that the person of Christ was the person of the obedient Son of the Father, who in his humanity remained in perfect holy communion with the Father from the very beginning, and so was sinless, and absolutely pure and spotless and holy. (p. 232)

However, even though Torrance claims that he used these terms in line with patristic classical definitions, Habets (2009:69) indicates that the inseparable usage of the anhypostastic and enhypostastic concepts in Christology was not evident in the patristic writings. Torrance (2008:84) himself acknowledges the absence of the couplet usage in the writings of the patristic fathers, as he contends that the ancient Catholic Church never really came to put anhypostasia and enhypostasia together in full complimentary' significance. Given this, Habets (2009:69) argues that Torrance combined these two concepts in his treatment of the doctrine of Christology in order to uphold 'the two natures of Christ within the one person' of the divine Logos. In this way, the anhypostasis and enhypostasis doctrines are closely linked in affirming the incarnational mystery of the divine and human nature in the one person of the eternal Son of God (Torrance 1996:131). However, regarding the stability of human nature, anhypostasis is the logically prior concept in that it recognises that Jesus' human nature does not have an alternative centre for grounding and expression, other than its enhypostatic grounding in the person of the divine Logos. Once this is established, it follows that all human beings find their true humanity in their enhypostatic existence in the existence of God (Torrance 2008:84).

Moreover, in determining the vicarious humanity of Christ by the anhypostastic and enhypostastic concepts, Torrance consistently grounds his doctrine of the vicarious humanity of Christ in the Trinitarian construct. Torrance (1995) grounds his doctrine of the vicarious humanity of Christ in Trinitarian theology, so that:

the very essence of the gospel and the whole of Christian faith depend on the centrality and primacy of the relation in being and agency between Jesus Christ and God the Father. (p. 3)

Here, Torrance sustains the oneness of God the Son and God the Father in being and agency in order to delineate the adequacy of Christ's salvation in all aspects of believers' lives. The oneness in being and agency between God the Son 
and the Father ${ }^{2}$ rests upon the homoousion concept, which states that the Son is of identical substance with the Father (Torrance 1995:199). This oneness in being of the Son and the Father does not cease in the event of the incarnation (Torrance 1996:214). Instead, it is an indivisible unity between the Son and the Father, which is in operation in the Son's redemptive work in the economy of salvation.

Thus, in the economy of salvation, we are confronted with the actuality that in becoming man, the Son of God never ceases to be identical with the Father, because they are of the same indivisible substance, yet distinguishable. Here:

through the homoousion, the incarnational and saving-revelation of God as the Father, Son and Holy Spirit was traced back to what God is enhypostatically and coinherently in himself, in his own eternal being as Father, Son and Holy Spirit. (Torrance 1995:199)

In agreement with Torrance, Moltmann (1974:234) contends that 'if this divine-human nature in the person of the eternal Son of God is the centre which creates a person in Christ', it follows that Christ saved humanity from the depth of his existence, as he suffered and died (on their behalf) for the sake of their redemption. That is, human salvation is not something external to God, but a permanent internal act of God in redeeming humanity from sin and all its consequences.

In this way, one can argue that in expressing his doctrine of the vicarious humanity of Christ, Torrance upholds the doctrine of Trinity and Christology together. This is why Habets (2009:68) contends that Torrance's theology is 'ProNicene- and Pro-Chalcedonian' in nature. ${ }^{3}$ Hence, in integrating the Nicene doctrine of Trinity and the Chalcedon doctrine of Christology (in order to forcefully delineate the vicarious humanity of Christ), Torrance (1995) agrees with Athanasius that:

[S]ince Jesus Christ is himself God and man in one person, and all his divine and human acts issue from his one Person, the atoning mediation and redemption which he wrought for us, fall within his own being and life as the Mediator between God and man. That is to say, the work of atoning salvation does not take place outside of Christ, as something external to him, but takes place within him, within the incarnate constitution of his Person as Mediator. (p. 155)

There are thus, three movements or theological constructs in Torrance's thought that come together to configure the theological truth of the ontological inclusivity of all mankind in the humanity of Jesus Christ with its salvific consequences, namely, homoousios, anhypostatsis and enhypostasis. Therefore,

2.The few passages which Torrance (1992:53) uses to depict the one being of the Son with the Father are Matthew 11:27 and Luke 10:22. In Torrance's (1992:54) view, these passages were used by the Church fathers (Patristic Fathers) because they affirm the exclusive 'mutual knowing between the incarnate Son and God the Father which implied a mutual relation of being between the Son and the Father... Here, 'the Father dwells in the Son and the Son dwells in the Father in a fully mutual relation of being and a relation of being and agency upo

3.For a detailed explanation of the Nicene formulation of the one being of God the Father and the Son, as well as the Chalcedonian doctrine of the unconfused true Father and the Son, as well as the Chalcedonian doctrine of the unconfused true
divine and true human nature in the one person of the Son of God, see Need divine and true human nature in the one person of the
(2008:41-60, 93-107) (also see Magezi \& Magezi 2016c). in the hypostatic union of the Son of God with man in the incarnation, all human beings (including Africans) are confronted with the reality that in Christ's death, resurrection and ascension, God acted within the depths of himself and human existence to save all mankind from $\sin ^{4}$ and all its consequences, including death and the negative impact of the invisible forces to humanity (Torrance 1995:4, 155, 175, 1996:203204, 224-233, emphasis added).

The aforesaid actuality of Christ's salvation in all aspects of believers' lives commences as they are eternally united to and participate in the vicarious humanity of Christ through faith in him and his redemptive work (Torrance 2009:213235, 1995:4-5). This eternal union and participation in the vicarious humanity of Christ is a result of the work of the Holy Spirit (cf. Jn 3:5; Rm 8:15) in uniting us to Christ ${ }^{5}$ (Torrance 1992:110, 1996: 249-250, 238). Owing to the divine alliance between Christ's redemptive acts and the agented work of the Holy Spirit (the work of the Holy Spirit is not apart from the work of Christ), all Christians are ushered into their eternal communion and fellowship with the Triune God (Torrance 1995:156). That is, Christians are 'not saved or renewed by the activity of Christ without being united to him and partaking of him' through the Spirit (Torrance 1995:139). Through faith in Christ:

our human relations with God, far from being allowed to remain on a merely external basis, are embraced within the Trinitarian relations of God's own Being as Father, Son and Holy Spirit. (Torrance 1992:64)

Therefore, Christians are 'in union with God in and through Jesus Christ' in whom their 'human nature is not only saved, healed and renewed but lifted up to participate in the very light, life and love of the Holy Trinity' (Torrance 1992:66).

\section{Torrance's connection between the doctrine of creation and redemption in the vicarious humanity of Christ}

Molnar (2007:93) agrees that Torrance (1995:83) proposes a connection between the doctrine of creation and redemption in the incarnation. Torrance (1995:83) integrates the vicarious humanity of Christ within his understanding of the doctrine of creation, in which the eternal Word of God is the creator of all existing things (Jn 1:3). In this endeavour, Torrance retains the centrality of the Christian doctrine of the Trinity, in which the incarnated Son of God should be understood as eternally one being with God the Father. In the light of the supremacy of Christ in Colossians (1:15-17, cf. Heb 1:3), Torrance (1995:83) further understands that Jesus Christ is the eternal incarnated Son of God 'by whom all creatures have been brought into being from nothing and in whom they all consist and hold together'. Once the sovereign role of the Son of God in creation is grounded in his eternal oneness in being with

4.At this juncture, Torrance (1992:xii) emphasises that in the incarnational "healing and saving relations with us, Jesus Christ is engaged in personalising and humanizing activity' in order to make us truly human: this is what God intends us to be.

5.The activity of the Holy Spirit in the economy of salvation (for humanity) is related 'to the atoning substitution in the life, death and resurrection of Jesus Christ' (Torrance 1996:238) 
the Father, Torrance utilises Proverbs 8:22 to affirm the Biblical truth that in the vicarious humanity of Christ (in the incarnation), the very Son of God 'had been created (became man) by God as the Beginning and Archetype of all God's providential and redemptive operations toward us' (Torrance 1995:83). In qualifying this statement, Torrance (1995:83) concurs with Athanasius in arguing that the author of Proverbs is not using the word 'created' in reference to the eternal co-existence of the Son with the Father. Instead, it is used in reference to the vicarious humanity of Christ in the incarnation, in which the Son of God became man 'in order to carry out God's saving and renewing work on our behalf' (Torrance 1995:83).

The preceding understanding of Proverbs (8:22) contradicts the interpretation of Arianism, which declares that Jesus Christ was a prerogative creature created by God in order to act as an instrument of God in bringing forth all creation into existence (Torrance 1995:83). Therefore, in Arianism's understanding, the Son of God is not properly God. In objection to Arianism, one should agree with Torrance (1995:83-84) that the author of Proverbs is pointing Christians to the mysterious act (of the incarnation) that in and through Jesus Christ, God himself stepped down (from his eternal transcendent and infinite existence) into the space and time of human existence in order to save us. Athanasius (1953:26), Barth (1956:58), Torrance (1995:83) and Hardy's (1981:89) understanding of Christ as both the Creator and the Saviour of all humankind is vital because it depicts the consistency between the doctrine of creation and redemption. Hardy (1981) explains the close association between the doctrine of creation and redemption in this way:

the agency operative in Jesus Christ and his redemption is not secondary to that in God's creation and history with the world, but that the world and its history are formed by the same agency as is seen at work in Jesus Christ and the redemption accomplished through him. (p. 89)

\section{In line with Hardy, Torrance (1981) proposes that:}

[T] he incarnation means that God has made himself present within his creation in an entirely new way, in that the eternal Word of God, the personal mode and activity of his being, by whom the universe was created and from whom it received its order and in whom it consists, has himself become man in Jesus Christ, in whom he makes our creaturely existence his own. (p. 134)

In the vicarious humanity of Christ, Christians are confronted with the actuality that the eternal Son of God is their Creator and Saviour of all human beings. To put it differently, in the incarnation, the Son of God had a couplet vicarious function to fulfil for mankind, namely, 'he is the actual way which God's saving economy has taken among us in this world, and the one way which leads us back to the Father' (Torrance 1995:84). Given this, Torrance (1995) upholds that:

$[T]$ he Christian doctrine of creation and its radicalization of contingency rest on the doctrine of the incarnation. It is as we think out together the doctrines of the incarnation and the creation that we find the whole structure of our understanding of God, Christ and the world being transformed. (pp. 110-111)
This suggests that Torrance (1981:134-135) integrates the doctrine of creation and redemption in the existence of the divine-human Son of God. In Torrance's (1981:135) view, the aspect of the divine-human nature in the one person of the divine Logos brings forth the certainty that in the incarnation, the entire fallen structures of human existence are being reordered, renewed and preserved by the same Creator (the eternal Son of God) who brought all existing things into being. The creation was fashioned by God the Father, in and through his eternal Son (Jesus Christ), and both the continual existence and sustenance of the entire creation are dependent on the independent, self-existing and infinite God (Barth 1956:56-58; Torrance 1981:135). Therefore, in the redemptive incarnation of Christ, we are witnessing God's union with contingent humankind for the sake of our re-creation, restoration and revitalisation into what God himself intends us to be. In other words, in and through Christ, God saved all mankind from its eternal corruption inherent in their Adamic sinful nature. Torrance (1981) helpfully encapsulates this point in his prolonged explanation:

$[T]$ he incarnation is to be interpreted as the alliance of the Creator with his creation in actualization of his will to make himself responsible for its preservation and salvation. In and through the incarnation of his beloved Son, God has laid hold of man in his contingency and in his disorder in order to make good his support of man's fleeting, evanescent creatureliness and rectify its eternal disruptions. (p. 135)

Kettler (1991:136) elaborates that the union between the Creator and all mankind in the incarnation aids Torrance in his argument that 'the vicarious humanity of Christ' is the point of 'integration between the fallen world and the Creator'. Here, Torrance understands that the vicarious humanity of Christ is fundamental for the eternal redemption of humanity (Kettler 1991:136). This implies that all human beings participate through their union with the humanity of Christ in the divinity of Christ for their salvation; hence, without their participation in the inner being of God himself, there is no salvation for human beings (Kettler 1991:136). In Torrance's view, the assumption of human nature by Jesus Christ (the Creator) is God's demonstration to sinful humanity that eternal 'reconciliation' between God and sinful humanity 'will take place in the context of God's own being', not outside of himself (Kettler 1991:136). To quote Torrance's (1995) words:

The redemptive work of Christ was fully representative and truly universal in range. Its vicarious efficacy has its force through the union of his divine person as Creator and Lord with us in our creaturely being, where he lays hold of us in himself and acts for us from out of the inner depths of his existence with us and our existence in him, delivering us from the sentence of death upon us, and from the corruption and perdition that have overtaken us. (pp. 155-156)

Here, Torrance is moving towards his establishment of the recapitulation concept, in which by the virtue of Jesus Christ being the Creator and the Saviour of all humanity, everything is now summed up in him as the head of all creation. Torrance puts it this way: Christ is: 
the Head of creation, in whom all things consist, he is the only one who really can act on behalf of all and save them. When he took our human nature upon himself, and in complete somatic solidarity with us offered himself up to death in an atoning sacrifice for man, he acted instead of all. (Torrance 1995:155)

Even though Ford (2013) agrees with Torrance's explanation of recapitulation, he amplifies Torrance, saying:

Recapitulation means that God's redemptive work found in Jesus Christ was not just a passing external shot into our time and space at only one point in history, but that He came into our existence and is at work within it, penetrating back to the beginning in the original creation retracing and re-affirming in it the divine Will, and reaching forward to the consummation in the new creation in which all things are gathered up, thus connecting the end with the beginning. (p. 26)

Therefore, one should recognise that Christ's redemption encompasses all aspects of life, including the dispelling of human beings' ignorance about God and his ways in the world, which extend to creation, and also to human perceptions about creation (Torrance 1996:203-204; 210). This is why Torrance $(1995: 84,1996: 204)$ concludes that:

as the arche in this creaturely economic form, Jesus Christ is the Head of all creation, the one source and controlling Principle with reference to whom we are to understand all the ways and works of God. (Torrance 1995:84, 1996:204)

\section{Torrance's interpretation of Israel's redemptive history from an incarnational perspective}

Torrance (2008:41-44) is certain that the redemptive history of Israel is realised in the incarnation of Jesus Christ (hence the vicarious humanity of Christ). In saying this, Torrance differs from those who conceive of a divide between Old Testament and New Testament redemptive history by detaching Jesus Christ from his relationship with the ancient history of Israel. In other words, Torrance's enterprise of treating the redemptive history of Israel from an incarnational perspective arises from his discontent with those who hold to the Christological doctrine of the divine and human nature 'in the unity of one person' of the divine Logos (Torrance 2008:37), yet disconnect Christ's person from the history of ancient Israel (Torrance, 1992:1). Torrance (2008:37) argues that the person and soteriological work of Christ is inseparable. The Old Testament and the New Testament are essentially one because the former anticipates the coming Messiah, and the latter looks back in fulfilment of the promises of the Messiah that came (Torrance 2008:44-45). In affirming this, Torrance (2008) understands the doctrine of incarnation as central in God's redemptive history for all mankind, as he contends that:

$[T]$ he center of gravity is in the incarnation itself, to which the Old Testament is stretched out in expectation, and the New Testament looks back in engulfment. This one movement throughout the Old Testament and New Testament is the movement of God's grace in which he renews the bond between himself to man in such a way as to assume human nature and existence into oneness with himself. (p. 45)
Because the incarnation is central in the interpretation of the redemptive history of Israel (hence, the Old Testament and New Testament redemptive history), Torrance (1992:3) proposes a two-fold approach to the doctrine of incarnation. Firstly, it interprets the history of Israel from an incarnational perspective, especially by considering the New Testament's application of the Old Testament titles to Christ, such as the 'Son of David' (Torrance 1992:3). Torrance contends that the conferring of Israel's sonship titles on Christ indicates Jesus Christ's 'intimate bond with Israel in its covenant relationship with God throughout history' (Torrance 1992:3). In this way, Torrance (1992:3) explores and develops the theological meaning of the incarnation by assuming the main tenets of the developed Christian understanding of the Son, and exploring the theme of sonship in the context of biblical theology. Secondly, this approach interprets Christ:

in light of what he is in himself in his internal relations with God, that is, in terms of his intrinsic significance disclosed through his self-revelation to us in word and deed. (Torrance 1992:3)

This two-fold approach keeps the person and the salvific work of Christ in an inseparable union (Torrance 2008:37). In asserting this, Torrance (2008:38) establishes that the treatment of the redemptive story of Israel under the doctrine of incarnation is a faithful representation of Scripture.

In his expansion of the interrelationship between the redemptive history of Israel and the doctrine of incarnation, Torrance $(2008: 45,58)$ argues that Israel was unmeritoriously chosen (out of God's grace and love) to venture into a covenantal relationship with God (Exodus 19:1ff. - the Sinai covenant), in which Israel was to act as the mediator of God's salvation to all humankind, that is, God ordained Israel to be an instrument of his salvation to all mankind (Torrance 2008:58). However, because Israel was part of the predicament of sin, Torrance concurs with Kruger's (2007) understanding that:

the covenant between God and Israel is a personal relationship of the deepest, most intimate order, in which the Lord is doing the impossible - overcome the contradiction between fallen humanity and Himself and establishing real communion, union and oneness. (p. 2)

Nevertheless, the understanding of Israel as an instrument of God's salvation to all mankind is deeply rooted in the Abrahamic covenant (i.e. Isaac, Jacob and the nation of Israel were part of the Abrahamic promises because they were Abraham's descendants), in which God promised to make Abraham a blessing to all the nations (Gn 12:1-3; cf. 17:1ff.) (Torrance 2008:58). That is, even though God promised some specific blessings to Abraham and his physical descendants (Gn 12:2), it is apparent that the Abrahamic covenant embraces all other nations; therefore, it was both 'particular and universal' in nature (Torrance 2008:51).

At this point, Torrance introduces us to the covenant sign of circumcision, which was established between God and Abraham (in which the covenant was to be cut into the flesh of Abraham and all his descendants as their symbol of 
covenant with God) as an anticipation of the incarnational event, in which the Word of God would enter into actual human existence for the sake of our redemption (Torrance 2008:48). Here, the mystery of incarnation stands as the definitive fulfilment of the anticipation of the Abrahamic covenant, the anticipation in which the Word of God was to be 'enacted so deeply into the existence of Israel' (Torrance 2008:48). The incarnation of Christ does not only fulfil the anticipation of the Abrahamic covenant (hence, Israel), but also inaugurates the new covenant between God and humanity, in which a 'new and living way was opened up in the humanity of the Son of God' (Torrance 2008:48). Nevertheless, although Torrance emphasises the supremacy of the incarnation over the redemptive history of Israel, he still upholds the significance of Israel, as he argues that:

[T] he adumbration of God's way of redemption is worked out more fully with Abraham, Isaac and Jacob. It is the way in which God comes in pure grace to gather frail humanity into covenant and communion with himself, and even provides for man a covenanted way of response to God's grace. Man approaches by faith, but in faith relies upon a divinely provided way of approach and response to God in the covenant. (Torrance 2008:40)

Significantly, in line with God's purpose for the election of Israel (namely, the role of bringing salvation to all humankind), Jesus Christ was the promised Saviour or Messiah from the womb of Israel, ${ }^{6}$ who came to fulfil Israel's role (Torrance 1992:5, 45). In saying this, Torrance (2008:38) is moving towards his redefinition of the redemptive history of Israel under the vicarious humanity of Christ. Torrance argues that:

theologically, we must say that when the Son of God breaks into that historical development, he throws it all into critical reorientation. The prehistory is critically and creatively reinterpreted by the incarnate Word. (Torrance 2008:37-38)

This is because, Jesus Christ (the ultimate fulfiller of the Abrahamic covenant and Israel's history) is the representative of all mankind because he is God himself who stepped into human history and assumed human nature for the sake of our redemption. That is, even though Jesus Christ possessed a close association with ancient Israel, it is clear that he surpasses Israel's redemptive role, once and for all, because he is the very God himself who identifies with all humankind (in the incarnation) and saved them all. With this settled, Torrance (2008:44) is ready to see the reinterpretation of the redemptive history of Israel (owing to the incarnation of the Son of God) as certain because:

The supreme instrument of God for the salvation of the world is Israel, and out of the womb of Israel, Jesus, the Jew from Nazareth - yet he was no mere instrument in the hands of God, but very God himself, come in person in the form of a servant, to work out

6.In Kruger's (2007:1) view, when Torrance says Israel was the womb of the incarnation, he means two specific things with which one should agree. Firstly Israel is considered the womb of the israe is considered the womb of the incarnation owing to her unique task within the broken world or creation; the task in which God in his redemptive plan was seekin to restore his "personal relationship with the fallen creation' through Israel as $h$ is instrument of that endeavour (Kruger 2007:2). Secondly, 'the womb refers to the provisional way of communion that God established with fallen humanity within Israel' (Kruger 2007:2). from within our limitations and recalcitrance, and to bring to its triumphant completion, the redemption of mankind, and our restoration to fellowship with the very life of God himself. (p. 44)

\section{The implications of Torrance's incarnational Christological model on the problem of the foreignness of Christ in African Christianity}

\section{The anhypostastic and enhypostastatic concepts affirm Christ's real identification with African Christians}

Torrance's understanding of the vicarious humanity of Christ as determined by the anhypostatic and enhypostatic union is vital in deepening African believers' understanding of their real identification with Christ. Here, anhypostatic union states that the human nature of Christ is without an independent centre of personhood because it finds its centre or expression in the person of the Son of God (enhypostatic union) (also see Magezi \& Magezi 2016b). Indeed, if the human nature of Christ does not have its own independent expression, and that this lies instead in the eternal Word, this makes room for the truth that the Word, the Creator, assumed a common human nature, not merely a discrete one (Graham 2012:45). In other words, the couplet significance of anhypostasia and enhypostasia brings to the forefront the reality that the human nature of Christ embraces all Christians, regardless of their tribal, national or genealogical categories (also see Magezi \& Magezi 2016b). This is because in the incarnation, Jesus Christ is God the incarnate, who fully identifies himself with all mankind by assuming a common human nature (Graham 2012:45; Torrance 2009:lxxv). Therefore, Jesus Christ is not a foreigner or stranger to African Christians. In this regard, the ontological inclusivity of all humankind in the vicarious humanity of Jesus Christ is an important foundational element in challenging African believers' continual reliance on traditional African powers to address their spiritual insecurity.

Further, the concepts of anhypostatic and enhypostatic union have a profound soteriological meaning (Graham 2012:45). They bring to the fore the actuality that 'God in Christ has acted for us in our place' (Torrance 2009:1xxv). On the one hand, anhypostasia means that as a human being, Jesus Christ 'has acted for all humanity' (Torrance 2009:Ixxv). On the other hand, enhypostasia means that as a human being, Jesus Christ 'has done so personally and individually for each and every human being' (Torrance 2009:1xxv). This means that Christ lived, died, resurrected and ascended in solidarity with all humanity because the union between God and humanity in the incarnation is a permanent indivisible union (Graham 2012:45; McGrath 1999:156-157). In this way, the couplet significance of anhypostatic and enhypostatic union confronts African believers with the actuality that in Christ's redemptive acts, God himself acted from the depth of our existence and his (God's) existence to change our sinful human nature. To use Torrance's (1981) words: 
the work of God in the incarnate life, crucifixion, and resurrection of Christ is not one that is forcibly imposed upon man (humanity) from above and from outside, but a work of God incarnate issuing from below and from within man (humanity). (p. 137)

\section{That is:}

[W] hile it is irreducibly the work of God in His saving penetration into the ontological depths of a human being, it is nevertheless the work of God as man, translated into and rising out of the human being as genuinely the work of man. (Torrance 1981:137)

Through the Son of God's assumption of a common human nature, God himself absorbed the penalty of $\sin$ and corruption for all humankind, and changed us from the depth of our human existence. This perspective arises from viewing the universal range of the doctrine of atonement as grounded in God. Once this is established, it follows that all true salvation and true human existence is now found in Jesus Christ because it is in the incarnation that the human nature acquires real existence in the existence of God.

However, Torrance is not a universalist in arguing for the ontological inclusivity of all humankind in the vicarious humanity of Christ. This qualification is important because we are aware that the notion of ontological inclusivity of all humankind in the vicarious humanity of Christ is capable of misunderstandings in a universalist direction. Recently, Molnar (2015:166; Torrance 2009:181-189) refers to Torrance's denial of universalism saying, universalism is a 'heresy for faith and a menace to the gospel' because even though Jesus Christ identifies with all humankind, not all people will be saved. ${ }^{7}$ Torrance maintains that all people become the beneficiaries of the redemptive acts of Christ as a result of their eternal union and participation in the vicarious humanity of Christ through faith. Through faith in Christ, and thus in his vicarious humanity, Christians realise their eternal union and participation in the redemptive acts of Christ, stretching from Christ's incarnation to his second coming (the parousia). In this regard, Thimell (2008:30) reinforces that in Torrance's view, faith 'does not create a new reality. It simply participates in an already completed event. And even that participation is a sharing in the faithfulness of Jesus'. Here, the redemption of all humankind was completed in and through Christ's redemptive acts on our behalf, as Jesus declared at the cross that it was all finished in him (John 19:30) (Thimell 2008:30). Thus, the eternal union and the participation of African believers in the vicarious humanity of Christ warrant one to argue that Christ's

7.Torrance $(2009: 183$, cf. 181-189) can be suspected of holding to the possibility of universal salvation if not handled carefully. In his extensive discussion concerning the scope of Christ's redemption, he argues for the inseparability of the doctrine of 'atonement and incarnation' because both flow 'out of the nature of God', which is to love all. That is, if in the incarnation, Christ fully identifies with all mankind, it follows that his death was also a death for all humankind (Mark 10:45 \& Matthew 20:28) (Torrance 2009:183). Here, the word 'many' in Mark 10:45 and Matthew 20:28 is translated in some New Testament texts (cf. 1 Tm 2:4-6; Tt 2:11-14, cf. Cor 5:14) as 'all' (Torrance 2009:183). However, in saying this, Torrance (2009:189) Cor 5:14) as all (Torrance 2009.183). However, in saying this, Torrance (2009:189) is not a Universalist because he is aware that some will reject the grace and love of God in the face of his universal intentions for humanity, which he accomplished in and through his incarnated Son, Jesus Christ. That is, objectively, Torrance (2009:189) prefers to 'think of atonement as a sufficient and efficacious reality for every human being - it is such sufficient and efficacious reality that it is the rock of offense, the rock of judgement upon which the sinner who refuses the divine lov shatters himself or herself and is damned eternally'. redemption is sufficient for African Christians in all of their existence. That is, through faith in Jesus Christ, the redemption of Christ is sufficient for all Christians because it is in the incarnation that God identifies with all humanity and then acts deep from within himself to save estranged humankind and restore us into our eternal communion with the Triune God.

\section{The connection between the doctrine of creation and redemption affirms Christ as both the Creator and Saviour of African Christians}

Torrance's close association between the doctrine of creation and redemption is helpful in establishing the complete identification of Christ with African Christians. The close association between the doctrine of redemption and creation shows that there is no disjunction between these two doctrines. That is, in the incarnation, the same Creator (God the Son) of all visible and invisible things is the one who vicariously acts for the redemption of all humankind. In redemption, as we have discussed, God in Christ acted from within the depths of himself to save us, not only from sin but also from the tyranny of the spiritual powers of darkness. In saying this, we are moving towards the declaration that Jesus Christ truly identifies with African Christians as both their Creator and Saviour in all aspects of life. Jesus Christ is not a stranger or foreigner to Africans; therefore, they can trust him fully for their spiritual security. In other words, in the incarnation, the Son of God, head of all creation, came into complete solidarity with all humankind so that he can truly save us from sin and evil.

By the virtue of Jesus Christ being the Creator, it follows that Jesus Christ is the only one who can save humankind from visible and invisible evils, which emerge as a result of Adam's $\sin (\mathrm{Gn} 3)$. In line with this understanding of Jesus Christ as both the Creator and Saviour of all humanity, it is important to reinforce that Christ's redemption for African Christians encompasses all aspects of life, including the dispelling of their ignorance about God and their perceptions of creation and his ways in the world. That is, the redemption of Christ is vast and comprehensive in nature. In this way, if God's salvation in and through Jesus Christ as both the Creator and Saviour is all encompassing, spanning both material and spiritual reality, then the African Christians' use of traditional African powers for their well-being and spiritual security is offensive to God because it depends on other powers rather than God's saving power revealed in Christ. This denies the notion of recapitulation (apakephalaiosis), which affirms the 'fulfillment of God's purposes for man (humanity) in and through the inclusive and vicarious humanity of Christ' (Torrance 1981:140). Therefore, to challenge African Christians' continued reliance on traditional African powers, we ought to understand, like Torrance (1995:84, 1996:204) that:

as the arche in this creaturely economic form, Jesus Christ is the Head of all creation, the one source and controlling Principle with reference to whom we are to understand all the ways and works of God. (Torrance 1995:84, 1996:204) 


\section{Torrance's interpretation of Israel's redemptive history from an incarnational perspective warrants African believers' identification with the biblical redemptive narrative}

Torrance's treatment of Israel's redemptive history from an incarnational perspective is vital because it enables African Christians to embrace the Bible story as their own salvific history, which finds its fulfilment in Christ's incarnation. This does not mean that Torrance does not consider the unique place of Israel in God's redemptive plan. He acknowledges Israel as the instrument of God's salvation for all nations, but because Israel was also part of the pandemic of sin, she failed in fulfilling her universal role to the world. Here, Torrance dwells on the Abrahamic covenant in order to highlight the significance of the relationship between the Abrahamic covenant and the nation of Israel in its universal role of bringing salvation to all humankind. Torrance highlights that the Abrahamic covenant was particular and universal in nature. On the one hand, the particularity of the Abrahamic covenant is that it has promises solely pertaining to Abraham and his biological descendants (Israel) (Gn 12:1-2). On the other hand, the universal aspect of the Abrahamic covenant is that it has a universal promise, in which Abraham and his descendants were to be a blessing to all nations (Gn 12:3).

Torrance remains in touch with the notion of Jesus belonging to the Abrahamic/Davidic line, especially by exploring the theme of sonship in the context of biblical theology. Phrases such as 'the Son of David' are used to contend that Jesus in the biological (human) sense belongs to the womb of Israel. However, although Torrance regards Christ in his intimate relationship with the nation of Israel, he is very aware that Jesus Christ was God incarnate (very God himself), who identifies with all humankind as both Creator and the Second Adam so that he can work out redemption for all people, hence, fulfilling the universal aspect of the Abrahamic promise. In other words, even though Jesus is from the womb of Israel, Torrance is aware that Jesus did not fulfil the unique role of Israel as a mere instrument of God, instead, he fulfilled it as God, who voided himself of his honour and glory (Phlp 2:5-11) in order to identify with all humanity so that he can suffer for the sake of our redemption. Thus, through faith in Jesus Christ, the biblical redemptive history of Israel extends to African Christians because the Old Testament and New Testament are a single redemptive story, which culminate in the incarnation of Jesus Christ, the very God himself.

In substantiation, it is important to stress that even though African believers appropriate the Abrahamic promises through faith in Jesus Christ, this does not mean that African Christians become Israelites. Instead, owing to their faith in Jesus Christ, African Christians are to understand that God has embraced them through the history of Israel. That is, because God's redemptive narrative, particularised in Israel, was also designed by God to extend to us (Gn 12:3b), it embraces all nations not by way of colonisation but as brothers in and of the New Adam through faith. Given this, Jesus Christ is not foreign to African Christians because through faith in him, they appropriate the divine promises given to the patriarchs of Israel and Israel as a nation (also see Magezi \& Magezi 2016a).

\section{Towards Torrance's Christological perspective - Christ's solidarity and identification with Africans: A perspective beyond ancestor ${ }^{8}$ categories}

The ancestors in Africa are described as blood-related members of the family, clan or tribe, who have lived an outstanding life and who have supposedly thereby acquired supernatural powers after death, which enable them to function as both guardians and protectors of their living descendants (Bediako 2004:23; Lugira 2009:48-50; Nyamiti 2006:3, 9; cf. Oladosu 2012:160-161) (also see Magezi \& Magezi 2016b). The ancestors are viewed as being closer to living people than any other spiritual power, and they can either harm or bless their living descendants depending on the existing relationship between them (ancestors and the living people) (Oladosu 2012:161; cf. Dyrness 1990:48; Mbiti, 1989:82; Triebel 2002:187) (also see Magezi \& Magezi 2016b). This is why Triebel (2002) captures the centrality of ancestors in African traditional beliefs by concluding that:

Because the ancestors cause misfortune on the one hand and because on the other hand only they can grant fortune, wellbeing, life, and a good living — that is, fullness of life-they alone are venerated.... Therefore this cult is really the central aspect, the center of African religion. (p. 193)

Given this, for Christ to be accepted by Africans and to fulfil the expected responsibilities in addressing their spiritual insecurity (which is believed by Africans to be the role of ancestors and other African traditional practitioners), the overarching concern is about the familial relationship between Jesus Christ of Nazareth and the African people because the two do not belong to the same 'clan, family, tribe and nation' (Bediako 2004:23; Pobee 1979:81; Reed \& Mtukwa 2010:158-161) (also see Magezi \& Magezi 2016a, 2016c). Owing to this perceived unrelatedness between Jesus Christ and African people, many African Christians 'are uncertain about how the Jesus of the Church's preaching saves them from the terrors and fears that they experience in their traditional world-view' (Bediako 2004:23) (also see Magezi \& Magezi 2016a, 2016c). Once Christ is depicted as a foreigner, it is perceived that he is unable and insufficient to address the spiritual insecurity of African Christians (Banda 2005:4-7). This requires the dispelling of the foreignness of Christ in African Christianity by providing a biblical explanation of the nature and extent of Christ's incarnation. In doing this, African Christians ought to fully identify

8.This section is not intended to discuss ancestors in any detail but to provide cursory perspective that Torannce's Christors an 1922; Ching 1992; Chitando 2005; Ezigbo 2008; Igba 2013; Kabasele 1991; Magezi 2016; Milingo 1984; Mkole 2000; Mugabe 1991; Nyamiti 2006; Olsen 1997; Palmer 2008; Pobee 1979; Reed \& Mtukwa 2010). 
themselves with Christ, as well as understanding Christ's involvement in all their existential challenges.

Therefore, to the end of ensuring Africans' identity and solidarity with Christ, Torrance's Christology provides a useful framework that transcends the ancestor category based on blood line such as in Africa to universal humanity (with Africans included). This Christological framework debunks and dispels the notion of a foreign Christ in Africa in at least four ways that have been established above. Firstly, the significance of anhypostasia and enhypostasia means that the human nature of Christ embraces all Christians, regardless of their tribal, national or genealogical categories. The incarnation means that Jesus Christ, God incarnate, fully identifies himself with all humanity by assuming a common human nature (Graham 2012:45; Torrance 2009:1xxv). Second is the soteriological meaning ushered by the concepts of anhypostatic and enhypostatic union. These concepts lay bare the reality that 'God in Christ has acted for us (humanity) in our place' (Torrance 2009:1xxv). Jesus Christ as a representative of humanity died for all humanity. Third is the association between creation and redemptive role of Christ to all humanity. In the incarnation, the same Creator (God the Son) acts for the redemption of all humankind. God in Christ acted from within the depths of himself to save humanity. Jesus Christ therefore truly identifies with African Christians as both their Creator and Saviour in all aspects of life. Fourthly, whilst Torrance regards Christ in his intimate relationship with the nation of Israel, Jesus Christ was God incarnate (very God himself), who identifies with all humankind as both Creator and the Second Adam so that he can work out redemption for all people. Christ therefore fulfils the universal aspect of the Abrahamic promise.

The above arguments regarding Christ's solidarity and identification with Africans stands as an important illustratory framework that indicates that Christ has indeed a blood line for all humanity (including Africans). The contention for blood line in African ancestors find fulfilment and satisfaction in Christ, thereby making him fully African as well (Christ ours in Africa!).

\section{Conclusion}

In conclusion, although Torrance does not explicitly engage with the problem of the foreignness of Christ in African Christianity, his construction of incarnational Christological concepts can open up avenues in Christ's person and work, which can be used to deepen African Christians' understanding of their complete identification with Christ. Torrance's framework portrays timeless Christological principles. Torrance's theological concepts were shown to be drawn from Greek patristic thought, namely, the anhypostatic and enhypostatic concepts of union can be employed to expound the vicarious humanity of Christ as the representative of all humankind. The anhypostatic concept refers to the fact that the human nature of Christ is without an independent centre of personhood, and the enhypostatic concept affirms that the human nature of Christ finds its centre or expression in the person of the eternal Son of God. This means that the human nature which was assumed by the person of the divine Logos, the Creator, is the common Adamic human nature, which embraces all humankind. To further deepen African Christians' comprehension of Christ's identification with all humankind (including Africans) an attempt was made to draw from Torrance's model the close association between the doctrine of creation and redemption, which affirms the actuality of Christ as both the Creator and Saviour of humankind. Torrance's interpretation of the redemptive history of Israel from an incarnational perspective warrants all Christians' identification of themselves with the biblical redemptive history of the Old Testament and the New Testament. Both the Old and New Testaments are essentially one redemptive narrative, which find its fulfilment in the incarnation of Christ. In this way, Torrance's incarnational Christological model has the significant implication that the gospel is for all humanity in its dealing with sin and spiritual forces. African Christians may claim complete solidarity with Christ everywhere without the stumbling block of a claimed foreignness of Jesus Christ.

\section{Acknowledgements Competing interests}

The authors declare that they have no financial or personal relationship(s) that may have inappropriately influenced them in writing this article.

\section{Authors' contributions}

Both authors contributed equally to this article.

\section{References}

Athanasius, 1953, St Athanasius on the incarnation, 2nd edn., Mowbray, London.

Banda, C., 2005, 'The sufficiency of Christ in Africa: A Christological challenge from African traditional religion', Dissertation - MA, University of South Africa, Pretoria.

Barth, K., 1956, Church dogmatics. The doctrine of the Word of God, 1. 2., transl. G. T. Thomson \& H. Knight, T. \& T. Clark, Edinburgh.

Barth, K., 1958, Church dogmatics. The doctrine of reconciliation, IV. 1., transl G. W. Bromiley \& T. F. Torrance, T. \& T. Clark, Edinburgh.

Bowers, P., 2002, 'African theology: Its history, dynamics, scope and future', Africa Journal of Evangelical Theology 21(2), 109-126.

Bowers, P., 2009, 'Christian intellectual responsibilities in modern Africa', Africa Journal of Evangelical Theology 28, 91-114.

Bavinck, H., 2006, Reformed dogmatics: Sin and salvation in Christ, vol. 3, Baker Academic, Grand Rapids, MI.

Bediako, K., 1994, 'Jesus in the African culture: A Ghanaian perspective', in A. Dryrness (ed.), Emerging voices in global Christian theology, pp. 93-121, Zondervan, Grand Rapids, MI.

Bediako, K., 2000, Jesus in Africa: The Christian gospel in African history and experience, Regnum Africa, Yaounde, Cameroun.

Bediako, K., 2004, Jesus and the Gospel in Africa: History and experience, Orbis Book, New York.

Bosch, D.J., 1993, Transforming mission: Paradigm shifts in theology of mission, Orbis Books, Maryknoll, NY.

Bujo, B., 1992, African theology in its social context, Orbis Books, Maryknoll, NY.

Cassidy, J.J., 2008, 'T. F. Torrance's realistic soteriological objectivism and the elimination of dualisms: Union with Christ in current perspective', Mid-America Journal of Theology 19, 165-194.

Chitando, E., 2005, 'Missionary attitudes towards African Traditional Religions and Hinduism. A comparative survey', in K. Koschorke (ed.), African identities and World Christianity in the twentieth century, pp. 181-197, Harrassowitz Verlag Wiesbaden.

Dyrness, W.A., 1990, Learning about theology from the third world, Zondervan, Grand Rapids, Ml. 
Ezigbo, V.I., 2008, 'Contextualising the Christ-Event: A Christological study of the interpretations and appropriations of Jesus Christ in Nigerian Christianity', Thesis - PhD, University of Edinburgh, Edinburgh.

Ford, B., 2013, 'T. F. Torrance and the problem of limited atonement: Faith seeking understanding for a pastor's theology of ministry', TM01 Theology of Ministry, viewed 23 February 2015, from https://www.gcs.edu

Gifford, P., 2008, 'Africa's inculturation theology: Observations of an outsider', Hekima Review 38, 18-34.

Graham, J.W., 2012, 'Is universalism theologically coherent? The contrasting views of P. T. Forsyth and T. F. Torrance', Evangelical Quarterly Journal 84(1), 40-46.

Habets, M., 2009, Theosis in the theology of Thomas Torrance, Ashgate, Farnham.

Hardy, D.W., 1981, 'Christ and creation', in T. F. Torrance (ed.), The incarnation: Ecumenical studies in the Nicene-Constantinopolitan Creed A.D. 381, pp. 87-110, Wipf \& Stock, Eugen, OR.

Igba, J., 2013, 'Ancestor Christology and Jesus' identity: A study based in the epistle to the Hebrews', Dissertation - MA, North West University, North West.

Imasogie, O., 1983, Guidelines for Christian theology in Africa, Africa Christian Press, Achimota.

Kabasele, F., 1991, 'Christ as ancestor and elder brother', in R. Schreiter (ed.), Faces of Jesus in Africa, pp. 103-115, Orbis Books, Maryknoll, NY.

Kato, B., 1975, Theological pitfalls in Africa, Evangel Publishing House, Kisumu.

Kettler, C.D., 1991, The vicarious humanity of Christ and the reality of salvation, Wipf \& Stock, Eugene, OR.

Kruger, B., 2007, On the road to becoming flesh: Israel as the womb of the incarnation in the theology of T. F. Torrance, PhD, viewed 23 February 2015, from https:// www.perichoresis.org

Kwesi, D., 1984, Theology in Africa, Orbis Books, Maryknoll, NY.

Lugira, A.M., 2009, World religions: African traditional religion, 3rd edn., Chelsea House Publishers, New York.

Magezi, C., 2016, The conceptualisation of Christ's salvation in Kwame Bediako and Thomas F. Torrance and its implications for spiritual security in African Christianity, North West University (Potchefstroom Campus), Potchefstroom.

Magezi, V. \& Magezi, C., 2016a, 'An Adamic incarnational Christological framework as a theological approach for African contextual ministry', Missionalia 44(2), 152-174.

Magezi, V. \& Magezi, C., 2016b, 'The immanence and transcendence of God in Adamic incarnational Christology: An African ethical reflection for the public', Verbum et Ecclesia 37(1), a1541. https://doi.org/10.4102/ve.v37i1.1541

Magezi, V. \& Magezi, C., 2016c, 'Pastoral care and healing in Africa: Towards an Adamic Christological practical theology imagination for pastoral healing', HTS Teologiese Studies/Theological Studies 72(2), a3467. http://dx.doi.org/10.4102/ Teologiese Studies,
hts.v72i 2.3467

Mashau, D.T., 2009, 'A reformed missional perspective on secularism and pluralism in Africa: Their impact on African Christianity and the revival of traditional religion', Calvin Theological Journal 44, 108-126.

Mbiti, J., 1989, African religions and philosophy, Heinemann, London.

McGrath, A.E., 1999, T. F. Torrance: An intellectual biography, T \& T Clark International, New York.

Milingo, E., 1984, The world in between: Christian healing and the struggle for spiritual survival, Orbis Books, Maryknoll, NY.

Mkole, J.C.L., 2000, 'Mark 14:62: Substantial compendium of New Testament Christology', HTS 56(4), 1119-1145.
Molnar, P., 2007, Incarnation and resurrection: Toward a contemporary understanding, William B. Eerdmans, Grand Rapids, MI.

Molnar, P., 2015, 'Thomas F. Torrance and the problem of universalism', Scottish Journal of Theology 68(02), 164-186. https://doi.org/10.1017/S00369 30615000034

Moltmann, J., 1974, The crucified God, SCM Press Ltd, London.

Mugabe, H.J., 1991, 'Christology in an African context', Review \& Expositor 88(4), 343-355. https://doi.org/10.1177/003463739108800403

Nakah, V., 2006, 'Evangelical Christianity and African culture', PhD thesis, Stellenbosch University, Cape Town.

Need, S.W., 2008, Truly divine and truly human: The story of Christ and the Seven Ecumenical councils, Hendrickson Publishers, Peabody, MA.

Nyamiti, C., 2006, Studies in African Christian theology, vol 2. Jesus Christ, the ancestor of humankind: An essay on African Christianity, CUEA Publications, Nairobi.

Oborji, F., 2008, 'African theology, Roman Catholic', in W.A. Dyrness \& V.M. Kärkkäinen (eds.), Global dictionary of theology: A resource for the world-wide church, pp. 15-20, IVP Academic, Downers Grove, IL.

Oladosu, O.A., 2012, 'Ancestral veneration in the religious expression of the indigenous Aladura Churches', Ogbomoso Journal of Theology XVII(2), 159-171.

Olsen, J.H., 1997, 'Contextualised Christology in tropical Africa', Svensk missionstidskrift $85(3-4), 247-267$.

Palmer, T., 2008, 'Jesus Christ: Our ancestor?', Africa Journal of Evangelical Theology 27(1), 65-76

Pobee, J., 1979, Towards an African theology, Abingdon Press, Nashville, TN.

Reed, R. \& Mtukwa, G., 2010, 'Christ our ancestor: African Christology and the danger of contextualization', Wesleyan Theological Journal 45(1), 144-163.

Sogolo, G.S., 1991, 'The concept of cause in African thought', in P.H. Cotzee \& A.P.J. Roux (eds), Philosophy from Africa: A text with readings, pp. 177-118, Oxford University Press, Oxford.

Taylor, J.V., 1963, The primal vision: Christian presence amid African religion, SCM Press, London.

Thimell, D., 2008, 'Torrance's Doctrine of Faith', Princeton Theological Seminary 39(2), 27-34.

Tienou, T., 1990, The theological task of the Church in Africa, 2nd edn., Africa Christian Press, Achimota.

Torrance, T.F., 1981, Divine and contingent order, Oxford University Press, Oxford.

Torrance, T. F., 1992, The mediation of Christ, W.B. Eerdmans Publishing Company, Grand Rapids, MI.

Torrance, T. F.., 1995, The Trinitarian faith, T \& T Clark, Edinburgh, NY.

Torrance, T.F., 1996, The Christian doctrine of God: One being three persons, T \& T Clark, Edinburgh, NY.

Torrance, T. F., 2008, Incarnation: The person and life of Christ, IVP Academic, Downers Grove, IL.

Torrance, T. F., 2009, Atonement: The person and work of Christ, IVP Academic, Downers Grove, IL.

Triebel, J., 2002, 'Living together with the ancestors: Ancestor veneration in Africa as a challenge for missiology', Missiology: An International Review XXX(2), 187-197.

Turaki, Y., 2006, Foundations of African traditional religion and world-view, Word Alive Publishers, Nairobi.

Wacheche, P., 2012, 'Modern trends in Christianity', Dissertation - MA, Nairobi University, Nairobi. 